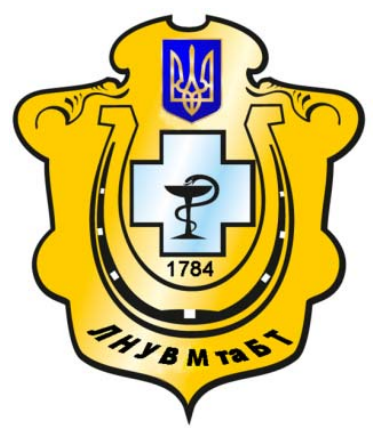

Науковий вісник Львівського національного університету ветеринарної медицини та біотехнологій імені С.3. Гжицького

Scientific Messenger of Lviv National University of Veterinary Medicine and Biotechnologies named after S.Z. Gzhytskyj

doi:10.15421/nvlvet6621

ISSN 2413-5550 print

ISSN 2518-1327 online

$\underline{\text { http://nvlvet.com.ua/ }}$

УДК 619:616-08:619:616.99:636.2

\title{
Вплив клозаверму А та катозалу на антиоксидантний статус організму корів за експериментального фасціольозу, сенсибілізованих ати- повими мікобактеріями
}

\author{
О.В. Куляба, В.В. Стибель, Б.В. Гутий \\ terena4@gmail.com
}

\begin{abstract}
Львівський національний університет ветеринарної медицини та біотехнологій імені С.3. Гжиџького, вул. Пекарська, 50, м. Львів, 79010, Украӥна
\end{abstract}

\begin{abstract}
У статті наведено результати досліджень впливу фасиіольозу та мікобактеріозу на активність ензимної ланки антиоксидантної системи та рівень продуктів перекисного окиснення ліпідів. Фасиіоли і мікобактерії пригнічують активність ензимів системи антиоксидантного захисту у печінці хазяїв, на що вказує зниження активності каталази на 23\%, супероксиддисмутази на 35\% та зростання рівня гідроперекисів ліпідів на 43\% (p < 0,001), ТБК-продуктів на 23\% (p<0,001) порівняно із здоровими тваринами.

Застосування дослідним коровам клозаверму А та катозалу сприяє зниженню ГПЛ та ТБК-активних продуктів у їх крові, запобігаючи розвитку оксидаційного стресу. Так, застосування тваринам дослідної групи Д. клозаверму А та катозалу сприяло швидиому підвищенню активності каталази, вже починаючи з 7 доби досліду. На 21 і 28 добу досліду активність досліджуваного ензиму коливалася у межах фізіологічних величин. Водночас у певному взаємозв'язку з інтенсивністю окисно-відновних прочесів у тканинах тварин перебуває активність СОД. На 21 добу досліду активність ензиму у дослідної групи Д 2 підвищилася на $34 \%$ відносно контрольної групи.

Аналіз одержаних результатів вказує, щзо супероксиддисмутазна активність в сироватці крові корів дослідних груп позитивно корелює з активністю каталази.

Після застосування клозаверму А для лікування корів за експериментального фасиіольозу, сенсибілізованих атиповими мікобактеріями, встановлено зниження інтенсивності прочесів перекисного окиснення ліпідів на 14 добу досліду ГПЛ на $11 \%$, а рівня ТБК-активних продуктів, відповідно, на 9\% відносно контролю.

Пригнічення процесів перекисного окиснення ліпідів за лікування тварин препаратами «Клозаверм А» та «Катозал» зумовлене активачією в організмі метаболічних процесів, у яких беруть участь ензими, у тому числі $i$ ензимиантиоксиданти, що каталізують процеси окиснення $і$ фосфорилювання, а також посиленням еритропоетичної функиї кісткового мозку.

Ключові слова: мікобактеріоз, фасиіольоз, клозаверм А, катозал, корови
\end{abstract}

\section{Влияние клозаверма А и катозала на антиоксидантный статус организма коров при экспериментальном фасциолезе, сенсибилизированных атипич- ными микобактериями}

\author{
О.В. Куляба, В.В. Стыбель, Б.В. Гутый \\ terena4@gmail.com
}

Львовский национальный университет ветеринарной медицины и биотехнологий имени С.3. Гжиџкого, ул. Пекарская, 50, г. Львов, 79010, Украина

Citation:

Kuljaba, O.V., Stybel, V.V., Gutyj, B.V. (2016). The influence of clozaverm A and catozal on antioxidant status of cows organism for the experimental fasciolosis, sensitized atypical mycobacteria. Scientific Messenger LNUVMBT named after S.Z. Gzhytskyj, 18, 2(66), 96-99. 
В статье приведены результаты исследований влияния фасциолеза и микобактериоза на активность энзимного звена антиоксидантной системь и уровень продуктов перекисного окисления липидов. Фасциоль и микобактерии подавляют активность ферментов системы антиоксидантной защиты в печени хозяев, на что указывает снижение активности каталазы на 23\%, супероксиддисмутазы на 35\% и рост уровня гидроперекисей липидов на 43\% (р < 0,001), ТБК-продуктов на 23\% ( $<<0,001)$ по сравнению со здоровыми животными.

Применение исследовательским коровам клозаверма А и катозала способствует снижению ГПЛ и ТБК-активных продуктов в их крови, предотвращая развитие оксидационного стресса. Так, применение животным исследовательской группы Д2 клозаверма А и катозала способствовало быстрому повышению активности каталазы, уже начиная с 7 суток опьта. На 21 и 28 сутки опьта активность исследуемого фермента колеблется в пределах физиологических величин. В то же время в определенной взаимосвязи с интенсивностью окислительно-восстановительных прочессов в тканях животных находится активность СОД. На 21 сутки опыта активность энзима в исследовательской группь Д2 повысилась на $34 \%$ относительно контрольной группьл. Анализ полученных результатов показывает, что супероксиддисмутазная активность в сыворотке крови коров исследовательских групп положительно коррелирует с активностью каталазыл.

После применения клозаверма А для лечения коров при экспериментальном фасциолезе, сенсибилизированньх атипичными микобактериями, установлено снижение интенсивности процессов перекисного окисления липидов на 14 сутки опьта ГПЛ на 11\%, а уровня ТБК-активных продуктов, соответственно, на 9\% относительно контроля.

Подавлению процесса перекисного окисления липидов при лечении животных препаратами «Клозаверм А» и «Катозал» обусловлено активацией в организме метаболических процессов, в которых участвуют энзимы, в том числе и энзимыантиоксиданты которые катализируют процессы окисления и фосфорилирования, а такље усилением еритропоетичнои функции костного мозга.

Ключевые слова: микобактериоз, фасциолез, клозаверм А, катозал, коровы.

\title{
The influence of clozaverm $A$ and catozal on antioxidant status of cows organism for the ex- perimental fasciolosis, sensitized atypical mycobacteria
}

\author{
O.V. Kuljaba, V.V. Stybel , B.V. Gutyj \\ terena4@gmail.com
}

\begin{abstract}
Lviv National University of Veterinary Medicine and Biotechnologies named after S.Z. Gzhytskyi,
\end{abstract}
Pekarska Str., 50, Lviv, 79010, Ukraine

The article deals with the results of researches of fasciolosis and myco bacteriosis on the activity of enzymatic antioxidant system level and the level of lipid peroxidation products.

Fasciola and mycobacteria inhibit the activity of enzymes of antioxidant defense system in the liver hosts, as indicated by decreased activity of catolase by 23\%, superoxide dismutase by 35\% and increase of lipid hydroperoxides level by $43 \%(p<0.001)$, TBA-products by $23 \%(p<0.001)$ compared with healthy animals.

The use of clozaverm A and catozale by research cows promotes the reducing of HPL and TBA-active products in their blood, preventing the development of oxidative stress. Thus, the use of clozaverm A and catozale by animal from the research groups contributed to rapid increase of catolase activity, beginning with the $7^{\text {th }}$ day of the experiment. At the $21^{\text {st }}$ and $28^{\text {th }}$ day of experiment the activity of investigated enzyme varies within the limits of physiological values. At the same time in a certain relationship with the intensity of redox processes in the tissues of animals is SOD activity. At the $21^{\text {st }}$ day of the experiment enzyme activity in experimental group D2 was increased by $34 \%$ compared to the control group.

The analysis of the obtained results indicates that superoxide dismutase activity in serum of cows of the research groups has positively correlated action with the activity of catolase.

After application of clozaverm $A$ for the treatment of cows by the experimental fasciolosis, sensitized atypical mycobacteria, is set the decrease in the intensity of lipid per oxidation at the $14^{\text {th }}$ day of the experiment HPL by $11 \%$, and the level of TBA-active products, respectively, by $9 \%$ compared to control.

The inhibition of lipid per oxidation for treatment of animal with drugs «Clozaverm A» and «Catozal» caused by activation of metabolic processes in the organism, which involve enzymes, including enzymes and antioxidants that catalyze oxidation and phosphorylation, and also by strengthening erytro poetical function of bone marrow.

Key words: mycobacteriosis, fasciolosis, clozaverm A catozal, cows

\section{ВстуII}

Одним 3 найбільш поширених і небезпечних гельмінтозів великої та дрібної рогатої худоби є фасціольоз, який завдає значних економічних збитків тваринництву: зниження молочної та м'ясної продуктивності, погіршення якості продуктів, витрати коштів на проведення лікувально-профілактичних заходів (Dovgij et al., 2000, Kuljaba and Stybel', 2015). Незважаючи на значні успіхи зарубіжних і вітчизняних вчених у вивченні фасціольозу, питання патогенного впливу фасціол на захисні системи організму тварин $є$ актуальним. Аналіз літературних джерел вказує на те, що гельмінти є сильними імунодепресантами та про щорічне поширення фасціольозу на території України, особливо в іiі західних, східних і південних регіонах (Kuljaba et al., 2015).

Повідомлення у вітчизняній та зарубіжній літературі також підтверджують те, що, поряд із фасціольозом великої рогатої худоби, значного поширення набув і мікобактеріоз (Kuljaba and Stybel', 2015; Kuljaba et al., 2015). Збудниками мікобактеріозу у тварин $\epsilon$ так звані потенційно патогенні мікобактерії (атипові, анонімні або некласифіковані), що характеризуються широким спектром природної лікарської стійкості (Kravciv et al., 2007; Litvinov et al., 2010). До того ж 
мікобактеріоз зазвичай розвивається тільки в ослабленому організмі тварин, котрі зазнали несприятливого впливу навколишнього середовища чи розвитку різних хвороб, включаючи паразитарні. Попри значну кількість досліджень, які присвячені вивченню фасціольозу у великої рогатої худоби, такі питання, як патогенетичні особливості фасціольозу у корів, сенсибілізованих атиповими мікобактеріями, їх адекватної терапії та профілактики захворювання, потребують поглиблених наукових підходів.

Метою нашої роботи було з'ясувати вплив клозаверму А та катозалу на антиоксидантний статус організму корів за експериментального фасціольозу, сенсибілізованих атиповими мікобактеріями.

\section{Матеріал і методи досліджень}

Для дослідів було відібрано 15 корів чорно-рябої породи, з яких сформовано 3 групи, по п'ять тварин у кожній. При проведенні досліджень дотримувалися правил, обов'язкових при виконанні зоотехнічних дослідів щодо підбору та утримання тварин-аналогів у групи, технології заготівлі, використання й обліку спожитих кормів. Раціон тварин був збалансований за поживними і мінеральними речовинами, які забезпечували їх потребу в основних елементах живлення.

Тварини контрольної групи були ураженні мікобактеріозом та фасціольозною інвазією. Коровам першої дослідної групи (Д) за експериментального фасціольозу, сенсибілізованим атиповими мікобактеріями, внутрішньом'язово вводили клозаверм А у дозі 0,5 мл препарату на 10 кг маси тіла тварини.

Тваринам другої дослідної групи (Д2), сенсибілізованим атиповими мікобактеріями, за експериментального фасціольозу внутрішньом'язово вводили клоза- верм А у дозі 0,5 мл препарату на 10 кг маси тіла тварини та катозал у дозі 10 мл препарату на тварину.

У плазмі крові визначали вміст гідроперекисів ліпідів і ТБК-активних продуктів згідно з методиками (Vlizlo, 2012). У сироватці крові досліджували: активність активність каталази (К.Ф. 1.11.1.6) - за методом М. А. Королюк (1988); активність супероксиддисмутази визначали (КФ 1.15.1.1.) - за методом Е.Е. Дубиніної (Vlizlo, 2012).

Кров для аналізу брали з яремної вени до зараження та на 7-, 14-, 21- і 28-у добу досліду.

\section{Результати та їх обговорення}

В останні роки увагу науковців привертає вивчення вільнорадикального окислення (ВРО) ліпідів мембран як регулятора фізіологічних процесів (Gutyj, 2012). За сучасними уявленнями, одним із універсальних типів ураження та причиною загибелі клітин різних органів $є$ надмірна інтенсифікація процесів перекисного окиснення ліпідів (ПОЛ) і пошкодження ними біологічних мембран (Martyshuk et al., 2016). Надмірна активація ПОЛ спричиняє порушення конформації та підвищення проникності біологічних мембран, вихід ензимів з мітохондрій і лізосом, інактивацію ензимів аеробного окиснення, роз'єднання окислювального фосфорилювання та мутації ДНК (Baglaj et al., 2011).

За експериментального фасціольозу у крові корів, сенсибілізованих атиповими мікобактеріями, відмічаємо посилення процесів перекисного окиснення ліпідів, на що вказує підвищений рівень гідроперекисів ліпідів та ТБК-активних продуктів.

Впли слозаверу А та гатозалу на рівень ПОЛ та стан САЗ у сироватці грові горів за експериментального фасціольозу, сенсибілізованих атиповими мікобактеріями $(\mathbf{M} \pm \mathbf{m} ; \mathbf{n}=\mathbf{5})$

\begin{tabular}{|c|c|c|c|c|c|c|}
\hline \multirow{2}{*}{ Показник } & \multirow{2}{*}{ 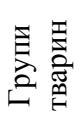 } & \multirow{2}{*}{ До зараження } & \multicolumn{4}{|c|}{ Термін досліджень (доби) } \\
\hline & & & 7 & 14 & 21 & 28 \\
\hline \multirow{3}{*}{ ГПЛ, од.Е/мл } & K & $1,83 \pm 0,03$ & $2,20 \pm 0,03$ & $2,37 \pm 0,05$ & $2,58 \pm 0,04$ & $2,64 \pm 0,04$ \\
\hline & $Д_{1}$ & $1,81 \pm 0,04$ & $2,05 \pm 0,06^{*}$ & $2,11 \pm 0,07^{*}$ & $2,15 \pm 0,02 * * *$ & $2,09 \pm 0,07 * *$ \\
\hline & Д $_{2}$ & $1,82 \pm 0,02$ & $1,90 \pm 0,05 * *$ & $1,97 \pm 0,04 * * *$ & $1,92 \pm 0,06^{* * *}$ & $1,81 \pm 0,06^{* * *}$ \\
\hline \multirow{3}{*}{$\begin{array}{l}\text { ТБК-активних про- } \\
\text { дуктів, } \\
\text { нмоль/мл } \\
\end{array}$} & $\mathrm{K}$ & $5,85 \pm 0,12$ & $6,33 \pm 0,10$ & $6,74 \pm 0,11$ & $7,02 \pm 0,12$ & $7,18 \pm 0,10$ \\
\hline & $Д_{1}$ & $5,82 \pm 0,10$ & $6,06 \pm 0,16$ & $6,15 \pm 0,17^{*}$ & $6,21 \pm 0,15^{* *}$ & $6,10 \pm 0,17 * * *$ \\
\hline & $Д_{2}$ & $5,84 \pm 0,11$ & $5,98 \pm 0,15^{*}$ & $5,94 \pm 0,17 * *$ & $5,89 \pm 0,17 * * *$ & $5,85 \pm 0,16^{* * *}$ \\
\hline \multirow{3}{*}{ КТ, мкат/л } & $\mathrm{K}$ & $47,18 \pm 1,10$ & $40,10 \pm 1,11$ & $38,75 \pm 1,12$ & $36,15 \pm 1,15$ & $38,14 \pm 1,13$ \\
\hline & $Д_{1}$ & $47,20 \pm 1,11$ & $43,40 \pm 1,12 *$ & $44,95 \pm 1,13 * *$ & $45,50 \pm 1,16^{* * *}$ & $46,30 \pm 1,17 * *$ \\
\hline & $Д_{2}$ & $47,31 \pm 1,10$ & $45,12 \pm 1,14 *$ & $46,40 \pm 1,10^{* *}$ & $46,9 \pm 1,18^{* * *}$ & $47,40 \pm 1,17 * * *$ \\
\hline \multirow{3}{*}{ СОД, у.о/мг білка } & $\mathrm{K}$ & $1,31 \pm 0,02$ & $1,17 \pm 0,03$ & $1,08 \pm 0,03$ & $0,96 \pm 0,03$ & $1,05 \pm 0,02$ \\
\hline & $Д_{1}$ & $1,33 \pm 0,02$ & $1,21 \pm 0,04$ & $1,12 \pm 0,02$ & $1,15 \pm 0,03 * *$ & $1,27 \pm 0,04 * *$ \\
\hline & Д $_{2}$ & $1,30 \pm 0,01$ & $1,25 \pm 0,01^{*}$ & $1,27 \pm 0,05^{*}$ & $1,29 \pm 0,04 * * *$ & $1,31 \pm 0,02 * * *$ \\
\hline
\end{tabular}

Після застосування клозаверму А для лікування корів за експериментального фасціольозу, сенсибілізованих атиповими мікобактеріями встановлено зниження інтенсивності процесів перекисного окиснення ліпідів, так на 14 добу досліду встановлено зниження рівня ГПЛ на $11 \%$, рівня ТБК-активних продуктів відповідно на 9\% відносно контролю. У подальшому рівень продуктів ПОЛ у крові дослідної групи Дз продовжував знижуватися і на 28 добу досліду рівень ГПЛ становив 2,09 \pm 0,07 од.Е/мЛ, ТБК-активних продуктів $6,10 \pm 0,17$ нмоль/мЛ, тоді як у контролі дані показник становили відповідно 2,64 $\pm 0,04$ од.Е/мл та 7,18 $\pm 0,10$ нмоль/мл.

Використання препаратів «Клозаверму А» та «Катозалу» для лікування корів за експериментального фасціольозу, сенсибілізованих атиповими мікобакте- 
ріями дозволило значно зменшити інтенсивність процесів ПОЛ в їх організмі. Вірогідне зниження продуктів ПОЛ спостерігаємо вже 314 доби досліду. На 21 і 28 доби досліду рівень ГПЛ і ТБК-активних продуктів доходи до фізіологічних величин

Отримані дані вказують на те, що за впливу клозаверму А та катозалу в організмі дослідних корів за експериментального фасціольозу, сенсибілізованих атиповими мікобактеріями, відбувається нормалізація окисно-відновних процесів та знижується рівень продуктів ПОЛ і як наслідок, інтоксикація організму.

У крові корів контрольної групи К встановлено низьку активність каталази - на 23\% нижче ніж у клінічно здорових тварин. Після лікування корів за експериментального фасціольозу, сенсибілізованих атиповими мікобактеріями, препаратом «Клозаверм А», відзначаємо нормалізацію активності ензиму у сироватці крові з 14 доби досліду. На 21 добу досліду активність каталази у сироватці крові дослідної групи Д 1 зросла на 26\%, а на 28 добу досліду відповідно на $21 \%$ відносно показників контрольної групи корів.

Застосування тваринам дослідної групи Д катозалу сприяло швидшому підвищенню активності каталази, починаючи 37 доби досліду. На 21 і 28 добу досліду активність досліджуваного ензиму коливалася у межах фізіологічних величин.

Разом $з$ тим, у певному взаємозв'язку з інтенсивністю окисно-відновних процесів у тканинах тварин знаходиться активність СОД. Супероксиддисмутаза є ключовим ензимом в системі антиоксидантного захисту. Зниження активності СОД у тварин контрольної групи корів за експериментального фасціольозу, сенсибілізованих атиповими мікобактеріями, за впливу різноманітних факторів може привести до збільшення вмісту перекисів ліпідів внаслідок активації процесів вільнорадикального окиснення.

Ми встановили, що на початок і кінець досліду активність СОД коливалася у межах 1,31 $\pm 0,02-0,96 \pm$ 0,03 у.о/мг білка. Застосування коровам дослідних груп препаратів «Клозаверму А» та «Катозалу» сприяло активізації активності супероксиддисмутази у їх сироватці крові, так на 21 добу досліду активність ензиму у дослідної групи Д 1 збільшилася на $20 \%$, а у дослідної групи Д - на 34\% відносно контрольної групи. Найвищою активність СОД була у сироватці крові тварин групи Д 2 на 28 добу досліду, де відповідно вона становила $1,31 \pm 0,02$ у.о/мг білка, що на $25 \%$ є вищою від величин контрольної групи корів.

Аналіз одержаних результатів вказує, що супероксиддисмутазна активність в сироватці крові корів дослідних груп позитивно корелює з активністю каталази.

\section{Висновки}

Застосування клозаверму А та катозалу коровам за експериментального фасціольозу, сенсибілізованих атиповими мікобактеріями, покращувало антиоксидантний статус їх організму, що супроводжувалось підвищенням у крові активності СОД на 25\% (р < 0,001) та каталази на $24 \%(\mathrm{p}<0,001)$ а також пригніченням інтенсивності процесів перекисного окиснення ліпідів, зниженням рівня гідроперекисів ліпідів на $31 \%$ (p $<0,001)$, ТБК-активних продуктів на 19\% $(\mathrm{p}<0,001)$.

\section{Бібліографічні посилання}

Baglaj, O.M., Murs'ka, S.D., Gutyj, B.V. (2011). Systema antyoksydantnogo zahystu ta perekysne okysnennja lipidiv organizmu tvaryn. Naukovyj visnyk L'vivs'kogo nacional'nogo universytetu veterynarnoi' medycyny ta biotehnologij imeni S. Z. G'zhyc'kogo. L'viv, 13, 4(50), 3-11 (in Ukrainian).

Gutyj, B.V. (2012). Vplyv hlorydu kadmiju na intensyvnist' procesiv perekysnogo okysnennja lipidiv ta stan systemy antyoksydantnogo zahystu organizmu shhuriv. Visnyk Sums'kogo nacional'nogo agrarnogo universytetu. Sumy, 7(31), 31-34 (in Ukrainian).

Dovgij, Ju.Ju., Vahovs'kyj, I.L., Semenenko, R.D. (2000). Zahvorjuvannja velykoi' rogatoi' hudoby, vyklykane parazytuvannjam fasciol $\mathrm{v}$ asociacii' $\mathrm{z}$ bakterijamy $\mathrm{i}$ grybamy. Visnyk Derzh. agroekol. akad. Ukrai'ny: Nauk.- teor. zb. Zhytomyr. 2, 115-118 (in Ukrainian).

Kravciv, R.J. Kuljaba, O.V., Turko, I.B., Semanjuk, V.I. (2007). Osoblyvosti vmistu bilkiv syrovatky krovi tvaryn, kontaminovanyh mikobakterijamy. Naukovyj visnyk L'vivs'kogo nacional'nogo universytetu veterynarnoi' medycyny ta biotehnologij imeni S. Z. G'zhyc'kogo. 9, 4(35), 74-78 (in Ukrainian).

Kuljaba, O.V., Stybel', V.V. (2015). Aktyvnist' enzymiv u syrovatci krovi koriv za fasciol'oznoi' invazii'. Naukovyj visnyk L'vivs'kogo nacional'nogo universytetu veterynarnoi' medycyny ta biotehnologij imeni S. Z. G'zhyc'kogo. 17, 1(2), 41-45 (in Ukrainian).

Kuljaba, O.V., Stybel', V.V. (2015). Stan imunnoi' systemy koriv za asociacii' mikobakterioziv ta fasciol'ozu. Naukovyj visnyk L'vivs'kogo nacional'nogo universytetu veterynarnoi' medycyny ta biotehnologij im. S. Z. G'zhyc'kogo. -17, 2, 309-313 (in Ukrainian).

Litvinov, V.I., Dorozhkova, I.R., Makarova, M.V., Krasnova, M.A., Frejman, G.E. (2010). Vydelenie i identifikacija netuberkuleznyh mikobakterij. Vestnik RAMN. 3, 7-11 (in Russian).

Martyshuk, T.V., Gutyj, B.V., Vishhur, O.I. (2016). Riven' produktiv perekysnogo okysnennja lipidiv $\mathrm{u}$ krovi shhuriv za umov oksydacijnogo stresu ta za dii' liposomal'nogo preparatu «Butaselmevit». Biologichnyj visnyk MDPU. 2, 22-27 (in Ukrainian).

Kuljaba, O.V., Stybel', V.V., Turko, I.B., Gutyj, B.V. (2015). Metodychni rekomendacii' «Zastosuvannja klozavermu A ta katozalu dlja korekcii' imunnoi' systemy organizmu koriv za fasciol'oznoi' invazii'». L'viv (in Ukrainian).

Vlizlo, V.V. (2012) Laboratorni metody` doslidzhen` u biologiyi, tvary`nny`cztvi ta vetery`narnij medy`cy`ni: dovidny`k. L`viv: Spolom (in Ukrainian).

Стаття надійшла до редакиії 5.09.2016 